moderate stroke. In patients with mild and moderate IS on the 7th day was observed reduced FA of cathepsin D while in the patients with severe IS - its increase.

Key words: ischemic stroke, acute period, cathepsin D.

SHEE I. Ya. Horbachevskyi State Medical University (Ternopil)

Рецензент - проф. В.М. Пашковський

(C) Н.Р. Сохор, С.І. Шкробот, О.В. Кулак, О.Р. Ясній, 2014
Buk. Med. Herald. - 2014. - Vol. 18, № 3 (71). - P. 140-144

Надійшла до редакції 21.04.2014 року

\title{
Г.Я. Ступницька
}

\section{СТАН СИСТЕМИ ГЕМОСТАЗУ ПРИ ХРОНІЧНОМУ ОБСТРУКТИВНОМУ ЗАХВОРЮВАННІ ЛЕГЕНЬ, ПОЄДНАНОМУ 3 ОЖИРІННЯМ}

Буковинський державний медичний університет, м. Чернівці

Резюме. При обстеженні хворих на хронічне обструктивне захворювання легень, поєднане з ожирінням, встановлена наявність гіперкоагуляційних змін, ступінь вираженості яких залежала від ступеня його тяжкості. Все це поряд із позитивними результатами паракоагуляційних проб, збільшенням вмісту розчинних фібрин-мономерних комплексів та ранніх продуктів деградації фібриногену у плазмі крові дають змогу

Вступ. Хронічна обструктивна хвороба легень (ХОЗЛ) є провідною причиною погіршення якості життя, інвалідності та смертності в усьому світі. Поширеність ХОЗЛ підвищується в більшості країни паралельно зі збільшенням кількості курців та постарінням населення. Всесвітня організація охорони здоров'я прогнозує, що до 2020 р. ХОЗЛ буде п'ятим за поширеністю захворюванням у всьому світі і третьою серед найпоширеніших причин смерті $[6,7]$.

Встановлено, що наслідком загострення ХОЗЛ може бути виникнення мікротромбозу легеневих судин, зумовленого активуванням тромбоцитів і гіперкоагуляцією крові[5]. Передбачається, що 3 порушеннями в системі гемостазу пов'язана частота розвитку пневмосклерозу і хронічного синдрому дисемінованого внутрішньосудинного згортання (ДВЗ) крові у хворих на ХОЗЛ [1].

Відзначається також висока розповсюдженість різних протромбогенних порушень згортальної і протизгортальної систем крові при ожирінні і метаболічному синдромі. При цьому порушення гемостазу виявлені вже при проведенні таких «скринінгових» тестів, як визначення активованого парціального тромбопластинового часу, міжнародного нормалізованого співвідношення і концентрації фібриногену в плазмі крові. Отримані дані про позитивну асоціацію вираженості окремих виявлених порушень гемостазу з антропометричними і біохімічними показниками вісце- передбачити наявність хронічного ДВЗ-синдрому 3 тривалим збереженням гіперкоагуляції при зазначеній патології.

Ключові слова: гемостаз, інгібітор активатора плазміногена-1, ожиріння, хронічне обструктивне захворювання легень.

рального ожиріння і метаболічного синдрому, параметрами ліпідного і вуглеводного обміну [4].

Водночас потребують подальшого вивчення порушення системи гемостазу за поєднаного перебігу ХОЗЛ та абдомінального ожиріння.

Мета дослідження. Дослідити зміни загального коагуляційного потенціалу крові та вмісту ІАП-1 у плазмі крові у хворих на ХОЗЛ, поєднане 3 абдомінальним ожирінням різного ступеня тяжкості.

Матеріал і методи. Обстежено 19 хворих на ХОЗЛ без ожиріння (1-ша група), 18 хворих на ХОЗЛ, поєднане з ожирінням I ступеня (2-га група), 12 хворих на ХОЗЛ, поєднане з ожирінням II ступеня (3-тя група), 12 хворих на ХОЗЛ, поєднане 3 ожирінням III ступеня (4-та група) та 18 практично здорових осіб (5-та група). Середній вік хворих становив $53,4 \pm 4,7$ року. За віковим і статевим складом між групами хворих і практично здорових осіб істотної різниці не було. Всі пацієнти інформовані про проведення дослідження і висловили свою згоду.

Індекс маси тіла (IMT, BMI - bodymassindex) визначався за формулою: $\mathrm{BMI}=\mathrm{m} / \mathrm{h}^{2}$, де $\mathrm{m}$-маса тіла (кг), а h-зріст (м). Оцінка маси тіла і ступеня ожиріння проводилася за класифікацією ВООЗ (1997): нормальна маса тіла - IMT 19-24,9 кг/м², надмірна маса тіла - IMT 25-29,9 кг/м², ожиріння I ступеня - IMT 30-34,9 кг/м2, II ступеня - IMT

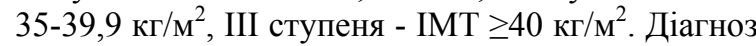


та стадію ХОЗЛ встановлювали згідно з Наказом MO3 України №128 від 19.03.2007 р.

Оцінювали загальний коагуляційний потенціал крові за часом рекальцифікації плазми (ЧРП), протромбіновим часом (ПЧ), тромбіновим часом (ТЧ) плазми крові, активованим парціальним тромбопластиновим часом (АПТЧ), рівнем фібриногену в плазмі крові, активністю антитромбіну III (ATIII), фактора XIII (ФXIII). Крім цього, досліджували рівень розчинних фібрин-мономерних комплексів (РФМК) та ранніх продуктів деградації фібриногену (РПДФ) у плазмі крові, проводили паракоагуляційні тести (етаноловий та протамінсульфатний) за допомогою наборів реактивів фірми "Danish Ltd.” (Львів) за методиками Н.Тіца [3]. Стан тромбоцитарносудинного гемостазу оцінювали за відсотком адгезивних тромбоцитів(ВАТ) [2], а також за індексом спонтанної агрегації тромбоцитів(ICAT) [10].

Вміст інгібітору активатора плазміногена-1 у крові визначали з використанням наборів реагентів "PAI-1" (Technoclone, Австрія) на імуноферментному аналізаторі "Униплан-М” (Росія).

Статистична обробка отриманих результатів виконана на персональному комп'ютері з викори- станням пакетів ліцензійних програм «MicrosoftExcel 2010» (Microsoft) та «Statistica ${ }^{\circledR}$ 6.0» (StatSoft Inc., США).

Результати дослідження та їх обговорення. Аналіз результатів проведених досліджень свідчить (табл. 1), що у хворих на ХОЗЛ без супровідної патології відзначена тенденція до вкорочення часових характеристик гемокоагуляції порівняно з групою практично здорових осіб. Зокрема, ЧРП зменшувався на $8,7 \%$, ПЧ - на $12,1 \%$, ТЧ - на $10,9 \%$ ( $>0,05)$. При цьому достовірним було тільки зменшення АПТЧ (на 13,3\%, p<0,05). Концентрація фібриногену в крові була збільшена на $28 \%$. Дослідження активності АТ III та Ф ХІІІ показали їх вірогідне зменшення на $10,95 \%(\mathrm{p}<0,05)$ та $14,85 \%$ $(\mathrm{p}<0,05)$ відповідно. Крім того, у хворих підгрупи Б 2-ї групи встановлене підвищення ВАТ, ICAT та IAП-1 (на 16,2\%, $<<0,05$; на 21,4\%, $<<0,01$; на $27,2 \%, \mathrm{p}<0,01$ відповідно).

У хворих на ХОЗЛ, поєднане $з$ ожирінням, зазначені зміни були істотнішими. Відзначено достовірне зменшення часу ЧРП - на 12,1\%; $19,3 \% ; 27,6 \%$, ПЧ- на $17,9 \% ; 23,8 \% ; 31,4 ;$ ТЧ - на $19,2 \% ; 23,9 \% ; 36,6 \%$; АПТЧ - на $19,1 \% ; 30,8 \%$;

Таблиця 1

Характеристика загального коагуляційного потенціалу плазми крові та вміст інгібітору активатора плазміногена-1 у плазмі крові при хронічному обструктивному захворюванні



\begin{tabular}{|c|c|c|c|c|c|}
\hline \multirow[b]{2}{*}{ Показники } & \multicolumn{5}{|c|}{ Групи обстежених } \\
\hline & $\begin{array}{c}\text { Хворі на ХОЗЛ } \\
\text { (1-ша група) } \\
\text { n=19 }\end{array}$ & \begin{tabular}{|c|} 
Хворі на ХОЗЛ, \\
поєднане з ожи- \\
рінням І ступеня \\
(2-га група) \\
n=18
\end{tabular} & $\begin{array}{c}\text { Хворі на ХОЗЛ, } \\
\text { поєднане } з \text { ожи- } \\
\text { рінням II ступе- } \\
\text { ня (3-тя група) } \\
\text { n=12 }\end{array}$ & $\begin{array}{c}\text { Хворі на ХОЗЛ, } \\
\text { поєднане з ожи- } \\
\text { рінням III ступе- } \\
\text { ня (4-та група) } \\
\text { n=12 }\end{array}$ & $\begin{array}{c}\text { Практично здо- } \\
\text { рові особи } \\
\text { (5-та група) } \\
\text { n=18 }\end{array}$ \\
\hline $\begin{array}{c}\text { Час рекальцифікації } \\
\text { плазми, с }\end{array}$ & $88,73 \pm 2,80$ & $85,49 \pm 2,13^{*}$ & $78,54 \pm 4,18^{*}$ & $\begin{array}{c}70,40 \pm 3,81 \\
* / * * * * * *\end{array}$ & $97,27 \pm 3,26$ \\
\hline Протромбіновий час, с & $21,39 \pm 0,94$ & $18,96 \pm 0,58^{*}$ & $17,59 \pm 0,74 * / * *$ & $\begin{array}{l}15,84 \pm 0,69 \\
* / * * / * * *\end{array}$ & $23,09 \pm 0,87$ \\
\hline Тромбіновий час, с & $15,84 \pm 0,51$ & $14,36 \pm 0,47^{*}$ & $13,53 \pm 0,52 * / * *$ & $\begin{array}{l}11,27 \pm 0,41 \\
* / * * / * * *\end{array}$ & $17,78 \pm 0,70$ \\
\hline $\begin{array}{c}\text { Активований парціаль- } \\
\text { ний тромбопластиновий } \\
\text { час, с }\end{array}$ & $31,92 \pm 1,15^{*}$ & $29,76 \pm 1,06^{*}$ & $25,46 \pm 1,29 * / * *$ & $\begin{array}{c}21,82 \pm 0,96 \\
* / * * / * * *\end{array}$ & $36,80 \pm 1,78$ \\
\hline $\begin{array}{l}\text { Концентрація фібрино- } \\
\text { гену в плазмі крові, г/л }\end{array}$ & $5,29 \pm 0,21 *$ & $5,40 \pm 0,17^{*}$ & $6,08 \pm 0,27 *$ & $\begin{array}{l}6,75 \pm 0,36 \\
* / * * * * * *\end{array}$ & $3,81 \pm 0,29$ \\
\hline $\begin{array}{c}\text { Активність } \\
\text { антитромбіну III, \% }\end{array}$ & $85,87 \pm 2,05^{*}$ & $81,13 \pm 1,33^{*}$ & $77,71 \pm 2,13 * / * *$ & $\begin{array}{c}68,54 \pm 0,91 \\
* / * * / * * * / * * * *\end{array}$ & $96,45 \pm 2,52$ \\
\hline $\begin{array}{c}\text { XIII фактор } \\
\text { згортання крові, \% }\end{array}$ & $84,41 \pm 1,95^{*}$ & $77,18 \pm 1,43^{*}$ & $73,56 \pm 1,85 * / * *$ & $\begin{array}{c}65,29 \pm 2,07 \\
* / * * / * * * / * * * *\end{array}$ & $99,13 \pm 3,04$ \\
\hline $\begin{array}{c}\text { Відсоток адгезивних } \\
\text { тромбоцитів, \% }\end{array}$ & $47,99 \pm 2,82 *$ & $54,81 \pm 2,15^{*}$ & $60,23 \pm 3,46 * / * *$ & $\begin{array}{l}68,75 \pm 2,89 \\
* / * * * * * *\end{array}$ & $40,20 \pm 2,23$ \\
\hline $\begin{array}{c}\text { Індекс спонтанної агре- } \\
\text { гації тромбоцитів, од. }\end{array}$ & $4,11 \pm 0,16^{*}$ & $4,98 \pm 0,28^{*}$ & $6,35 \pm 0,77 * / * *$ & $\begin{array}{l}7,86 \pm 0,96 \\
* / * * / * * *\end{array}$ & $3,21 \pm 0,25$ \\
\hline $\begin{array}{c}\text { Інгібітор активатора } \\
\text { плазміногена-1, нг/мл }\end{array}$ & $36,21 \pm 2,03^{*}$ & $44,78 \pm 1,54 * / * *$ & $\begin{array}{c}56,21 \pm 2,87 \\
* / * * * * * *\end{array}$ & $\begin{array}{c}73,45 \pm 3,68 \\
* / * * / * * * * * * * *\end{array}$ & $28,46 \pm 1,31$ \\
\hline
\end{tabular}

Примітка. * - відмінності достовірні (р<0,05) між показниками 1-ї та 5-ї, 2-ї та 5-ї груп; 3-ї та 5-ї груп; 4-ї та 5-ї груп; ** - відмінності достовірні (p<0,05) між показниками 2-ї та 1-ї, 3-ї та 1-ї; 4-ї та 1-ї груп; *** - відмінності достовірні $(\mathrm{p}<0,05)$ між показниками 3-ї та 2-ї; 4-ї та 2-ї груп; **** - відмінності достовірні $(\mathrm{p}<0,05)$ між показниками 3-ї та 4-ї груп 
Таблиця 2

Вміст розчинних фібрин-мономерних комплексів і ранніх продуктів деградації фібриногену в плазмі крові та результати тестів паракоагуляції при хронічному обструктивному захворюванні легень, посднаному з абдомінальним ожирінням різного ступеня $(\mathrm{M} \pm \mathrm{m})$

\begin{tabular}{|c|c|c|c|c|c|}
\hline \multirow[b]{2}{*}{ Показники } & \multicolumn{5}{|c|}{ Групи обстежених } \\
\hline & $\begin{array}{c}\text { Хворі на } \\
\text { ХОЗЛ } \\
\text { (1-ша група) } \\
\text { n=19 }\end{array}$ & \begin{tabular}{|c|} 
Хворі на ХОЗЛ, \\
поєднане з ожи- \\
рінням \\
І ступеня \\
(2-га група) \\
n=18 \\
\end{tabular} & $\begin{array}{c}\text { Хворі на ХОЗЛ, } \\
\text { поєднане з ожи- } \\
\text { рінням } \\
\text { II ступеня } \\
\text { (3-тя група) } \\
\text { n=12 } \\
\end{array}$ & $\begin{array}{c}\text { Хворі на ХОЗЛ, } \\
\text { поєднане з ожи- } \\
\text { рінням } \\
\text { III ступеня } \\
\text { (4-та група) } \\
\text { n=12 } \\
\end{array}$ & $\begin{array}{c}\text { Практично } \\
\text { здорові } \\
\text { особи (5-та } \\
\text { група) } \\
\mathrm{n}=18\end{array}$ \\
\hline $\begin{array}{l}\text { Розчинні фібрин-мономерні } \\
\text { комплекси та ранні продукти } \\
\text { деградації фібриногену, мкг/л }\end{array}$ & $4,87 \pm 0,32^{*}$ & $8,22 \pm 0,43 * / * *$ & $11,54 \pm 0,68 * / * * / * * *$ & $\begin{array}{c}15,40 \pm 1,15 \\
* / * * / * * * * * * * *\end{array}$ & $2,79 \pm 0,28$ \\
\hline Етаноловий тест & $7 / 19$ & $9 / 18$ & $8 / 12$ & $11 / 12$ & $0 / 18$ \\
\hline Протамінсульфатний тест & $7 / 19$ & $9 / 18$ & $8 / 12$ & $11 / 12$ & $0 / 18$ \\
\hline
\end{tabular}

Примітка. * - відмінності достовірні (р<0,05) між показниками 1-ї та 5-ї, 2-ї та 5-ї груп; 3-ї та 5-ї груп; 4-ї та 5-ї груп; ** - відмінності достовірні (р<0,05) між показниками 2-ї та 1-ї, 3-ї та 1-ї; 4-ї та 1-ї груп; *** - відмінності достовірні $(\mathrm{p}<0,05)$ між показниками 3-ї та 2-ї; 4-ї та 2-ї груп; **** - відмінності достовірні (р<0,05) між показниками 3-ї та 4-ї груп

40,7\% за I, II, III ступеня ожиріння відповідно $(\mathrm{p}<0,05)$. Спостерігалося збільшення концентрації фібриногену в плазмі крові (на 41,7\%; 59,6\%; 77,2\% відповідно в 2-й, 3-й та 4-й групах, $\mathrm{p}<0,001)$.

Встановлено також істотне збільшення ВАТ (на $36,3 \% ; 49,8 \% ; 71 \%$ відповідно, р<0,001), ICAT (на 55,1\%; 97,8\%; 144,9\% відповідно, $\mathrm{p}<0,001$ ) та вмісту ІАП-1 у плазмі крові (на 57,3\%; 97,5\%; 158,1\% відповідно, р<0,001) за одночасного зниження активності АТ III (на $15,9 \% ; 19,4 \% ; 28,9 \%$ відповідно, $\mathrm{p}<0,01)$ і Ф ХІІІ (на $22,1 \% ; 25,8 \% ; 34,1 \%$ відповідно, $<<0,001$ ).

При цьому відмінності між досліджуваними показниками в 1-й та 4-й, 2-й та 4-й групах були вірогідними $(\mathrm{p}<0,05)$; у 1-й та 3 -й групах - щодо всіх параметрів, крім ЧРП та концентрації фібриногену; у 1-й та 2-й, 2-й та 3-й групах - тільки щодо вмісту ІАП-1 у плазмі крові; у 3-й та 3-й групах - щодо активностей АТ III та Ф XIII та вмісту ІАП-1 в плазмі крові.

У 36,8\% осіб 1-ї групи, 50\% осіб 2-ї групи, 66,6\% осіб 3-ї групи та 91,7\% осіб 4-ї групи були позитивними паракоагуляційні (етаноловий та протамінсульфатний) тести. Істотним було збільшення рівня РФМК та РПДФ у плазмі крові (у 1,$75 ; 2,9 ; 4,1 ; 5,5$ раза відповідно в 1-й, 2-й, 3-й та 4-й групах, $\mathrm{p}<0,001)$ з достовірними міжгруповими відмінностями (табл. 2).

Отже, поглиблення гемокоагуляційних розладів є одним із механізмів прогресування ХОЗЛ на тлі ожиріння. Відомо, що інгібітор активатора плазміногена-1 (ІАП-1) у фізіологічних умовах $\epsilon$ важливим фактором регуляції фібринолізу, який синтезується як ендотеліальними клітинами, так і мегакаріоцитами. Встановлений підвищений рівень ІАП-1 у хворих 3 ожирінням, на думку M.Michalskaetal. [9], є не тільки наслідком вивільнення його з тромбоцитів при мікротромбозі, але й результатом його продукції вісцеральною жировою тканиною. Вважається, що ІАП-1 бере участь у ремоделюванні тканини під час розвитку ожиріння [8]. Як медіатор запалення, ІАП-1 може відігравати певну роль у патогенезі ХОЗЛ [11].

\section{Висновки}

При хронічному обструктивному захворюванні легень зміни з боку гемокоагуляційної ланки гемостазу характеризуються вкороченням активованого парціального тромбопластинового часу згортання крові, зменшенням активностей антитромбіну II та фактору XIII згоратння крові на тлі збільшення вмісту фібриногену та інгібітору активатора плазіногена-1 у плазмі крові, а також відсотка адгезивних тромбоцитів та індексу спонтанної агрегації тромбоцитів.

При поєднаному перебігу хронічного обструктивного захворювання легень та ожиріння сукупність усіх застосованих гемостазіологічних тестів свідчить про наявність у пацієнтів гіперкоагуляції крові, яка виявлялася збільшенням прокоагулянтної та пригніченням протикоагулянтної активності.

Позитивні результати паракоагуляційних проб на тлі збільшення вмісту розчинних фібринмономерних комплексів та ранніх продуктів деградації фібриногену у плазмі крові дають змогу передбачити наявність синдрому хронічного дисемінованого внутрішньосудинного згортання крові 3 тривалим збереженням гіперкоагуляції при хронічному обструктивному захворюванні легень. Зазначені зміни поглиблюються за наявності супутнього ожиріння залежно від ступеня його тяжкості.

Перспектива подальших досліджень полягає у вивченні особливостей стану системи гемостазу у хворих на хронічне обструктивне захворювання легень залежно від фенотипу супутнього метаболічного синдрому. 


\section{Література}

1. Полунина О.С. Состояние системы гемостаза у больных хронической обструктивной болезнью легких у пожилых / О.С. Полунина, И.А. Михайлова, И.А. Кудрявцева // Фундаментальные исследования. - 2005. № 2. - C. 32-33.

2. Мищенко В.П. Простой метод определения адгезивноагрегационных свойств тромбоцитов / В.П. Мищенко, Н.В. Крохмаль, К.А. Надутый // Физиол. ж. - 1980. - Т. 26, № 2. - C. 282-283.

3. Тиц Н. Энциклопедия клинических лабораторных тестов / Пер. с англ. под ред. В.В. Меньшикова. - М.: Лабинформ, 1997. $-960 \mathrm{c}$.

4. Шишкова В.Н. Развитие основных нарушений гемостаза у пациентов с ожирением / В.Н. Шишкова, А.Ю. Ременник, Л.И.Зотова // Кардиология. - 2012. T. 52, № 2. - C. 59-64.

5. Ashitani J. Elevated plasma procoagulant and fibrinolytic markers in patients with chronic obstructive pulmonarydisease / J. Ashitani, H. Mukae, Y. Arimura [et al.] // Int. Medicine. - 2002. - Vol. 41, № 3. - P. 181-185.
6. Calverley P.M. Chronic obstructive pulmonary disease / P.M. Calverley, P. Walker // Lancet. - Vol. 362. P. 1053-1061.

7. Global burden of COPD: systematicreview and metaanalysis / R.J. Halbert, J.L. Natoli, A. Gano [et al.]// Eur. Respir. J. - 2006. - Vol. 28. - P. 523-532.

8. Mertens I. Visceral fat as a determinant of fibrinolysis and hemostasis / I. Mertens, L.F. Van Gaal // Semin. Vasc. Med. - 2005. - Vol. 5, № 1. - P. 48-55.

9. PAI-1 and $\alpha 2-\mathrm{AP}$ in patients with morbid obesity / M. Michalska, I. Iwan-Ziętek, W. Gniłka [et al.] // Adv. Clin. Exp. Med. - 2013. - Vol. 22, № 6. - P. 801-807.

10. Taccola $\mathrm{A}$. Su un metodo di determinarione quantitativa della aggregabilita plastrimica spontanea / A. Taccola, G.B. Gotti, F. Baruffini [et al.] // Rass. Med. Sper. 1980. - Vol. 27, № 12. - P. 137-143.

11. Xu X. Plasminogen activator inhibitor-1 promotes inflammatory process induced by cigarette smoke extraction or lipopolysaccharides in alveolar epithelial cells / X. Xu, H. Wang, Z. Wang, W. Xiao // Exp. Lung Res. - 2009. Vol. 35, № 9. - P. 795-805.

\section{СОСТОЯНИЕ СИСТЕМЫ ГЕМОСТАЗА ПРИ ХРОНИЧЕСКОМ ОБСТРУКТИВНОМ ЗАБОЛЕВАНИИ ЛЕГКИХ С СОПУТСТВУЮЩИМ ОЖИРЕНИЕМ}

\section{А.Я. Ступницкая}

Резюме. При обследовании больных хроническим обструктивным заболеванием легких с сопутствующим ожирением установлено наличие гиперкоагуляционных изменений, степень выраженности которых зависела от степени его тяжести. Все это наряду с положительными результатами паракоагуляционных проб, увеличением содержания растворимых фибрин-мономерных комплексов и ранних продуктов деградации фибриногена в плазме крови позволяют предположить наличие хронического синдрома диссеминированного внутрисосудистого свертывания с длительным сохранением гиперкоагуляции при указанной патологии.

Ключевые слова: гемостаз, ингибитор активатора плазминогена-1, ожирение, хронические обструктивные заболевания легких.

\section{HEMOSTATIC SYSTEM IN CHRONIC OBSTRUCTIVE PULMONARY DISEASE WITH CONCOMITANT OBESITY}

\section{A.Y. Stupnytska}

Abstract. The examination of patients with chronic obstructive pulmonary disease with concomitant obesity established the presence of hypercoagulable changes, the severity of which depended on its degree. All this, along with the positive results of paracoagulation samples, increasing of soluble fibrin monomer complexes and early degradation products of fibrinogen in the blood, suggest the presence of chronic disseminated intravascular coagulation with prolonged retention of hypercoagulable in such pathology.

Key words: hemostasis, plasminogen activator inhibitor-1, obesity, chronic obstructive pulmonary disease.

Bukovinian State Medical University (Chernivtsi)

Рецензент - проф. Т.М. Христич

Buk. Med. Herald. - 2014. - Vol. 18, № 3 (71). - P. 144-147

Надійшла до редакції 10.06.2014 року

(C) Г.Я. Ступницька, 2014 